to prepare a careful hand to attend the feeding of them, for upon this depends the whole success of the attempt". The Society concerned itself with fisheries and manufactures in addition to its main objective. It did not survive the upheaval of 1745 , but for twenty years supplied a need which more permanent societies were later to satisfy.

\section{Research in Germany}

TrE issue of Die Naturwissenschaften for May 26 is devoted to the work of the Kaiser Wilhelm Gesellschaft zur Forderung der Wissenschaften and extends to more than eighty pages. The year ending March 1933 has been a difficult one for the society, and the hope is expressed that the Government will in the future be able to afford it more financial support. Its membership is now 786, a fall of more than 40 on the year. Its headquarters-Harnack Houseprovides accommodation for the meetings of more than thirty societies in addition to those of its own sections, daily meals for 160 scientific workers, and has put up for short stays 230 visitors during the year. Evening lectures, by distinguished members of the staff, have been given both at headquarters and in other towns of Germany as in previous years. In addition to outline reports of the work of each Institute, lists of papers published by the staffs are given, and both show how much the society is doing by scientific research to increase the welfare of Gernany and to maintain its position amongst those bent on "improving natural knowledge".

\section{Annual Meeting of the French Chemical Society}

Tre French Chemical Society is holding its annual general meeting in Paris on June 15-17; at the same time it is commemorating the bicentenary of the birth of Priestley. Among the distinguished foreign visitors at the meeting are Sir William Pope, professor of chemistry in the University of Cambridge, who has been asked to preside over the opening meeting; Prof. Morgan, president of the Chemical Society ; Prof. H. E. Armstrong; Prof. J. Böeseken, professor of organic chemistry in the Technical High School at Delft, who is speaking on the configuration of the polyalcohols; and Prof. E. Spath, professor of chemistry in the University of Vienna, who is discussing recent syntheses of alkaloids. An address on "Priestley and his scientific Work" was to be given on June 15 by Prof. C. Matignon, professor of inorganic chemistry in the Collège de France, and president of the Society. Priestley, by a decision of the National Council, was made a French citizen and was a member of the Academy of Sciences.

\section{"Empire Forestry Handbook"}

THE Empire Forestry Association has recently published a new edition of the "Empire Forestry Handbook" (Empire Forestry Association, Grand Buildings, Trafalgar Square, London. 5s.). The handbook contains much useful information, including a list of the officers and members of the Empire Forestry Association, and forestry officers serving in different parts of the British Empire. This is followed by a digest of education and research in forestry throughout the Empire, including lists of the universities and research institutes which contain forestry departments, together with the heads of departments and research workers. A list of forest periodicals is appended. The section on forest resources of the Empire contains a wealth of useful statistics concerning forest areas, and production, exports, etc., of conifers and hardwoods. The "Handbook" concludes with a list of the trade and botanical names of Empire timbers.

\section{Lister Institute of Preventive Medicine}

THE report of the governing body, presented at the annual general meeting of the Lister Institute of Preventive Medicine on May 24, gives a survey of the scientific work carried out during the year in the various departments. This includes studies on the viruses of variola, vaccinia, and varicella by Drs. Ledingham and Amies, on the typhus group of diseases by Dr. Felix, and researches on nutrition and vitamins in the Division of Nutrition under Dr. Harriette Chick. The nature and function of phosphoric esters formed during alcoholic fermentation have been studied by Prof. Robison and his collaborators. The National Collection of Type Cultures is housed in the Institute, and more than 5,000 strains of bacteria and fungi have been distributed to workers at home and abroad, and some 200 types have been added to the collection. The total expend. iture for the year was $£ 43,258$, and the excess of income over expenditure $£ 10,362$.

\section{National Institute for Research in Dairying}

THE annual report for the year ending July 31 . 1932, of the National Institute for Research in Dairying, University of Reading, which has only recently been issued, gives a summary of the research work carried out in the various departments. This includes a study of typical English milk, experiments on the feeding of young dairy cattle, and details of schemes for controlling the cleanliness of milk delivered by producers to retailers. Dr. H. Davenport Kay has been appointed to succeed the late Dr. Stenhouse Williams as director of the Institute. The financial position remains substantially the same as in the previous year, and additional income is still needed to stabilise the present position, and without reference to the ultimate needs of the Institute.

\section{Franklin Institute Medals}

Among the medal awards recently made by the Franklin Institute, Pennsylvania, are the following : Franklin medal, founded in 1914 by Mr. Samuel Insull, of Chicago, and awarded to those workers in physical science or technology whose efforts have done most to advance a knowledge of physical science or its application, to Dr. Orville Wright, of Dayton, Ohio, in recognition of the valuable investigations carried out by him and his brother, Wilbur, from which they obtained the first reliable scientific data 